\title{
The Dilemma of Global Capitalism and Ethical Reflection in Transmission
}

\author{
Yao-hung Haung \\ Tatung University, Taipei, Taiwan
}

\begin{abstract}
This essay focuses on the overwhelming influence of global capitalism, in which the eruption of the Žižekian Real serves as the disruptive subversion. This essay suggests that the reading of Žižek’s and Derridean ethical notions not only shed light on the present global disappointment, but unfold a complementary critical facet in our democratic society. In order to explore the complexity and contradiction of capitalism in Transmission, my reading locates the working of global capitalism as a psychoanalytical mode of drive and desire. These two modes become two elementary motivations forming one's dream of being wealthy and the nightmare of being abandoned in Hari Kunzru's Transmission. In the novel, the Indian computer engineer, Arjun Mehta, desires to save his job by creating a computer virus, which, I aver, turns out to trigger the eruption of the Žižekian Real, dissolving the exclusive domain of global capitalism. Both Arjun and the CEO of Tomorrow, Guy Swift turn out to be the victims of global capitalism, even though the former believes in American dream and the later believes in the power of the future. It is the traumatic experience that shatters Guy's dream of global capitalism and triggers his absolute responsibility to the other. It also shatters Arjun's strong faith in global capitalism. I argue that it is imperative for readers to review the devouring drive of global capitalism to eschew the devastating consequence, by the reflecting ethically on global capitalism. Both Žižek and Derrida’s ethical reflection may offer us a way out of the dilemma of global capitalism.
\end{abstract}

Keywords: Hari Zunzru, Derrida, Žižek, Absolute Responsibility, The Gift of Death, Specters of Marx, Ethics

\section{Introduction}

When the Berlin wall was demolished two decades ago, we were celebrating the end of cold war and expecting the prosperous development. We thought the world would become one peaceful global village without the threat of mutual destruction. Yet after years of global incorporation, today we are haunted by endless financial crises and social uprisings throughout the world. During these years, we have embraced the strategy of free market and multinational investment that should bring more jobs and opportunities. From GATT (The General Agreements on Tariffs and Trade) to WTO (World Trade Organization), we have erased economic barricades and established close economic business, cooperation and investment among nations. Many multinational corporations have achieved a great success and many more people have benefited from their success. Yet, we still face constant crisis of finance, exploitation, unemployment, and illegal immigrants in the age of global capitalism.

Yao-hung Haung, Adjunct Asistant Professor, Department of Applied Foreign Languages, Tatung University. 
To explore what causes today's dilemma, we need to find a proper literary text of global capitalism and its concomitant influence. The 2005 novel Transmission by Hari Kunzru not only exposes the dilemma of global capitalism but suggests an ethical reflection and solution.

Soon after the publication of Transmission, critics have acknowledged its contribution to unfolding the threat and predicament of global capitalism. In the interview, Kunzru himself admits that his novel aims to unfold not just "the loss of a particular sense in a globalized world" but "the tension between the global and local" (Aldama, 2008, p. 14). For Ashley T. Shelden, Kunzru’s Transmission presents a "cosmopolitan love” that crates a "global ethics allowing for the admission of difference without demanding the assimilation of these differences to universal sameness" (Shelden, 2012, p. 348). With the cosmopolitanism, Kunzru offers a "critique of globalization” (Shelden, 2012, p. 366). By concentrating on the computer virus in Transmission, Philip Leonard underscores that the hacking act is a form of resistance against "neo-liberal narratives of global inclusion" (Leonard, 2013, p. 267). Liam Connell avers that Kunzru's novel reveals the "systematic exploitation” of global capitalism in the name of fighting terrorism (Connel, 2013, p. 39). For Lucia Kramer, Transmission involves an “implicit meta-fictional reflection on... global and transcultural readership” (Kramer, 2013, p. 78). Kramer states the significant reflection of the novel on both global and transcultural viewpoints. Despite their different focuses and explorations, critics have recognized the contribution of Kunzru's Transmission to the relationship between ethics and global capitalism.

This essay examines Hari Kunzru’s Transmission from a Žižekian perspective, with references to Derridean ethical reflection. It focuses on the overwhelming influence of global capitalism, in which the eruption of the Žižekian Real serves as the disruptive subversion. This essay suggests that the reading of Žižek and Derrida's ethical notions not only sheds light on the present global disruption and disappointment, but unfolds a complementary critical facet in our democratic society. My reading will rely on Kunzru's novel Transmission to locate its working to explore the complexity and contradiction of global capitalism. I aver that the mechanism of global capitalism works on two psychoanalytical modes: drive and desire, which become two elementary motivations forming not just the dream of being wealthy but the nightmare of being abandoned in Transmission. Oscillating between Lacanian drive and desire, global capitalism satisfies our most craving fantasy, which explains its popularity throughout the world. In the novel, the Indian computer engineer, Arjun Mehta, desires first to work in an American company, and later to save his job by creating a computer virus, which, I aver, turns out to trigger the eruption of the Žižekian Real. The intrusion of the real dissolves the exclusive domain of global capitalism. Both Arjun and the CEO of Tomorrow, Guy Swift turn out to be the victims of what they believe, the rule of global capitalism, even though the former believes in American dream and the later believes in the power of the future. I argue that it is imperative for readers to review the devouring drive of global capitalism to eschew the devastating consequence by reflecting ethically on the accumulation mechanism of global capitalism. Both Žižek and Derrida’s ethical reflection may offer us a way out of the dilemma of global capitalism.

Yet, before I proceed to discuss the novel, I need to clarify the definition of global capitalism. For Žižek, capitalism is the "value which, through its circulation, generates more value, value which mediates-posits itself, retroactively positing its own presuppositions" (Žižek, 2006, p. 59). In other words, the true aim of capitalism is "simply more money, the endless repeating of the circulation” (Žižek, 2006, p. 60). In "Global Capitalism and the State," Jan Aart Scholte writes that “capitalism has adopted global forms of organization in respect of 
business associations" so as to locate bigger market, benefit, lower cost of production, taxation and cheaper labor (Scholte, 1997, pp. 437-38). In Transmission, this explains why Arjun Mehta is chosen by Sunny Srinivasan, the staff of Databodies. His remark to Arjun reveals the true goal of global capitalism:

I'll tell you a secret, Arjun-I don't know the difference between SOL and HTML. And I don't care. To me it's all letters. What I care about is butts-good, properly qualified desi butts sitting on good American office chairs, earning good consultancy dollars for Databodies and for me. Understand?” (Kunzru, 2005, p. 9)

For Sunny, "earning good consultancy dollars" is of the greatest importance. Disregarding the professional knowledge, he is there only to guarantee the profitability of the American company. In the meantime, global capitalism is the mechanism that guarantees Sunny to cross the earth to find cheap and quality labor since he says they are "cheap" (Kunzru, 2005, p. 44) and the most "cost effective” (p. 17). Therefore when Arjun tries to thank him, Sunny simply ends his conversation by saying "No, thank you, Arjun. Good to have you abroad” (Kunzru, 2005, p. 10). It is Arjun who is helping the expansion of the company. In return, the company only satisfies Arjun with empty American dream (Kunzru, 2005, p. 36).

In order to reach its cost effective profitability and efficient control, global capitalism generates "major difficulties for the realization of democracy through the state" (Scholte, 1997, p. 439). Influenced by global capitalism, leaders of the state ignore the democratic procedure, and clandestinely comply with entrepreneurs and conglomerates even to sacrifice the social welfare and universal justice. Kojin Karatoni sees this characteristic of global capitalism as that of neo-liberalism, which resembles the working of imperialism (Karatani, 2014, pp. 276-77). The characteristics of neo-liberalism include cutting back on social welfare and reducing taxes and regulations on capital (Karatani, 2014, p. 277). In neo-liberalism, the "livelihoods of the national people are necessarily sacrificed in the name of international competitiveness” (Karatani, 2014, pp. 278-79). In other words, neo-liberalism must become a both inclusive and exclusive mechanism to create an internationally competitive society. In Transmission, the leaders of the European Union tell Guy how they will "promote Europe as somewhere you want to go, but somewhere that's not for everyone ...”(Kunzru, 2005, p. 239). They want to transform Europe into an "exclusive" and "upscale" "continent that wants people, but only the best" (Kunzru, 2005, p. 239). They will ensure a prosperous and competitive EU with no poor illegal immigrants and "terrorists" (Kunzru, 2005, p. 234) with “regulations, statistics, directives and action plans” (Kunzru, 2005, p. 232). They will save no one but only the richest and most talented citizens. Most important of all, these ideas of transforming EU into a competitive place are made only by a small group of people, instead of the democratic process.

Yet, global capitalism does not only work with inclusive, exclusive and nondemocratic mechanism. It gains its global popularity with crucial factors. For Zizek, global capitalism works depending on two of our mental elements: desire and drive. First, desire is grounded in its constitutive lack (a void within the space), while drive circulates around a hole, a gap in the order of being (which is more radical designating a point at which this spatial order itself breaks down) (Žižek, 2006, p. 60). Capitalism interpellates individuals as "consumers, as subjects of desire, soliciting in them ever new perverse and excessive desires (for which it offers products to satisfy them)" (Žižek, 2006, p. 61). In the novel, when leaders of EU discuss how well the "economic power of Hollywood" promotes America and its commodity through the media, they stress that people believe in American icon as "the biggest and best" "like a religious faith" (Kunzru, 2005, p. 238). People blindly pursue the American 
dream with strong desire even when it is "rubbish," "most polluted," and "the most dangerous” (Kunzru, 2005, p. 238). The US interpellates the individuals, like Arjun and Guy, to regard everything related to the American icon or white man as the best.

On the surface, the mechanism of global capitalism seems to work on desire of the individual. But in practice, it is supported by the other crucial element: drive. For Zizek, drive inheres to global capitalism at a more fundamental, systematic level. "Drive which propels the whole global capitalist machinery is the impersonal compulsion to engage in the endless circular movement of expanded self-reproduction” (Žižek, 2006, p. 61). In the novel, for Guy, his company, Tomorrow, serves as a brand and commodity of the future. What he and his company do is to "take a business and transform it from being abstract thing into an entity that consumers can feel emotional toward” (Kunzru, 2005, p. 169). Yet, he never senses that fact that his whole life and company build on an abstract thing: a hole and a gap in the order of being. His life and the whole company are driven by the impersonal compulsion in the endless circular movement. Due to this empty drive, Guy must concentrate on the future to discover and transform empty "results" into his innovation and success (Kunzru, 2005, p. 19). As a result, Guy works like an animal driven by an invisible carrot in the front.

After unfolding how global capitalism works on desire and drive, we need to shift to see how Derrida views global capitalism and its victim. Derrida sees global capitalism as neo-liberalist hegemony (Derrida, 1994, p. 37 Specters of Marx). In democracy of neo-liberalism, "electoral representativity or parliamentary life is not only distorted, as was always the case, by a greater number of socio-economic mechanisms, but it is exercised with more and more difficulty in a public space...” (Derrida, 1994, p. 79). With the advent of neo-liberalism/global capitalism, Derrida demands us to notice its victim, which he names as the New International (Derrida, 1994, p. 85). The New International is the excluded, nameless and marginalized absolute other "without status, without title, and without name, barely public even if it is not clandestine without contract, “' out of joint,'... without country, without national community” (Derrida, 1994, p. 85). In the novel, when Guy is mistakenly apprehended in an immigration raid, he is turn into the New International. He is given a number and thrown into a group of illegal immigrants (Kunzru, 2005, p. 261). Because of his "shouting for help... ," Guy is eventually treated with "his hands and legs cuffed to a wheelchair” (Kunzru, 2005, p. 263). Like an animal, "tape is stuck over his mouth to stop him from shouting and a motorcycle helmet is shoved down over his head to prevent him biting his escorts or knocking himself out” (Kunzru, 2005, p. 263). As the New International, Guy is completely deprived of his title, status, and name. In the illegal immigrant camp, he has no contract with the outside world. When treated as an animal, Guy is transformed from an absolute VIP of British business world into an absolute excluded other.

Following the discussion of the New International as the absolute other, I proceed to discuss how the computer virus as the Lacanian real exposes and dissolves the mechanism of global capitalism. For Zizek, "the social reality is nothing but a fragile symbolic cobweb that can at any moment be torn aside by an intrusion of the real” (Žižek, 1992, p. 17). The real is the void and black hole of the symbolic that must be filled out by fantasy. Zizek states that this intrusion of the real designates not only the abyssal act of freedom, but the contradiction of the symbolic (Žižek, 1992, p. 65). Therefore, it is the "ultimate traumatic unbearable referent that we are unable to confront directly" (Žižek, 2003, p. 67). As the real always dissolves the symbolic reality, it can only be "shown as the interruption or breakdown of the process of signification” (Žižek, 1997, p. 279). If we want to find an object to indicates the abyssal real, the Žižekian Odradek/lamella of "inhuman-human undead organs without a 
body... which has escaped the symbolic colonization” can be used to stand for the embodiment of the Real (Žižek, 2006, pp. 117-118). The intrusion of the real not only dissolves the working of the symbolic but exposes its brutal violence.

In Transmission, Leela virus that serves the inhuman-human undead organ without a body has not only escaped and dissolved the symbolic colonization of global capitalism but reveal its problem. Though she appears as a female image in the computer, Leela is "not one thing" and is "not even a set or a group or a family" (Kunzru, 2005, p. 107). Leela shows up with "new forms at will, never staying stable for long enough to be scanned and recognize” (Kunzru, 2005, p. 107). Every generation creates “an entirely new Leela, her organ rearranged, mutated, hidden under a novel layer of encryption” (Kunzru, 2005, pp. 107-108). When Leela01 is captured and neutralized, "Leela02” or "Leela Server” will appear. Thanks to the connection of global capitalism, Leela as the real appears to disrupt the symbolic rules, functions and boundaries throughout the world. The life in the whole world was placed in chaos. Leela causes "brownouts” and “disruption” in London (Kunzru, 2005, p. 132). In the US, it is regarded as “deliberate negativization, threat or hostile intent” (Kunzru, 2005, p. 145). It is later seen as "the enemy within, a technological fifth column in the homes of ordinary Americans” (Kunzru, 2005, p. 145). After infected by the Leela08 virus, the European "Schengen Information System "randomly associates database attributes, was responsible for the destruction of a huge number of EU immigration records” (Kunzru, 2005, p. 263). This infection not only erases global capital records, but also results in false deportation and "gaps that have never been filled” (Kunzru, 2005, p. 254). The information disaster brings about the disappearance of large amount of money (Kunzru, 2005, p. 254). And the same information system identifies the innocent European citizens as "criminals, failed asylum seekers, or persons being monitored by European intelligence services" (Kunzru, 2005, p. 264). As the symbolic, global capitalism, which is designed to guarantee the free flow of capital and talented personnel, now erases the record of capital and persecutes the innocent effectively. The real exposes the violence and contradiction of global capitalism.

Yet, it is not until the exposure of the violent and contradictory symbolic that Guy begins to change his attitude towards global capitalism. The intrusion of the real obliquely leads the subject to break up the rotary movement of global capitalism between drive and desire (Žižek, 2006, p. 65). In the chaotic disruption, the subject is given a momentary glimpse and suspension to transcend the economy of global capitalism. To transcend the mechanism of global capitalism, we need to delve into the basic economic working of global capitalism. Karatoni has stresses that the original mode of capitalism is the accumulation of money since it triggers "a desire for power" (Karatoni, 2014, p. 94). He also suggests that the only solution to transcend the economic mode of global capitalism is an alternative kind of exchange economy (Karatoni, 2014, p. 230).

Concerning the alternative one, Derrida discusses a kind exchange economy: the non-calculating gift of death, which transcends the capitalistic economy of exchange based on "parity and symmetry" (Derrida, The Gift of Death 102). While the exchange economy of global capitalism works on equality and calculation, Derrida presents an alternative kind of exchange transgressing and eschewing the economy of equal and calculating exchange. In the Derridean exchange economy, the traditional gift exchange of giving, receiving and reciprocation is completely destroyed by the gift-of-death. One must have the absolute responsibility and see the other as "infinitely other in its absolute singularity...” (Derrida, 1996, p. 78) since God, "as wholly other, is to be found everywhere” (p. 78). When one recognizes every other as the partial embodiment of the wholly other (that 
is, absolute singularity), one will sense his absolute responsibility to the absolute singularity, and give the other the gift without "wanting recognition and payment in terms of a calculable salary, in terms of thinks or recompense" (Derrida, 1996, p. 107). Therefore, I aver that the intrusion of the Zizekian real enables the individual to not just break though the vicious circle of capitalistic accumulation between drive and desire, but recognize the other as the absolute singularity. When the subject recognizes every other as the partial embodiment of the wholly other, he will forsake the calculating economy of global capitalism. Only by giving up the calculating economy can the subject truly obtain an ethical position and avoid repeating the devastating result.

In Transmission, we can sense the change of Guy's attitude from the economy of symmetrical exchange to the economy of the gift of death. At first, Guy lives in a society where "there was a calculus... an assessment of value" (Kunzru, 2005, p. 123). The human relations works on "what you had to trade” equally (Kunzru, 2005, p. 123). In his book, Guy Swift: The Mission, Guy writes that "the future is happening today, and in today's fast-moving future the worst place to do business is the past, I strive to add value by surfing the wave of innovation" (Kunzru, 2005, p. 19). He is convinced that the future can be predicated and calculated. He can profit a lot by creating and controlling the future for himself and his clients (Kunzru, 2005, p. 212). But after the abrupt intrusion of Leela virus, Guy is suddenly placed into a place of exile excluded by the symbolic system he loves: global capitalism. As an illegal immigrant, Guy experiences a sudden suspension in his incessant pursuit for future oscillating between desire and drive. In Albania, he experiences the life of a beggar "foraging for scraps behind restaurants in the city center” (Kunzru, 2005, p. 264). Under that circumstance, Guy comes to recognize the other as "infinitely other in its absolute singularity ..." (Derrida, 1996, p. 78). In Albania, he is no longer a wealthy British entrepreneur carving for future and opportunity to accumulate fortune. He senses the brutal violence of global capitalism.

Therefore, when Guy comes back from Albania, he becomes a humble potter and no longer has any interest in any business (Kunzru, 2005, p. 259). When his former assistant, Kika Willis is asked about him, she replies that "he wasn’t Guy anymore" and "something turned him into a freak” (Kunzru, 2005, p. 257). In the little country village, he is a "sincere man" who sales "sincere pot" (Kunzru, 2005, p. 259). After his return to the UK, Guy forsakes his identity of the "London media agency boss" (Kunzru, 2005, p. 258). He refuses the capitalistic economy as well as its oscillation between desire and drive. On the contrary, Guy talks about the earth as the source of life (Kunzru, 2005, p. 258) which is a sign of seeing everyone as the absolute singularity. He follows a non-calculative economy of exchange as his healing power and sales his ceramics with "unconditional refund," and helps a crew of local men to repair field walls (Kunzru, 2005, p. 259).

\section{Conclusion}

In Transmission, due to the intrusion of the real, Guy not only sees the violent and contradictory working of the global capitalism (brutal exploitation and exclusion of the New International) but abandons the belief in global capitalsim. Kunzru's novel gives us a perfect picture of how global capitalism is ruling and manipulating the choices of our life. It also suggests an ethical way of solving the dilemma of global capitalism after the fall of Berlin wall. During these years, we have witnessed the success of entrepreneurs and multinational corporations. We have also seen innumerable riots and crises globally. Yet almost every leader of the state claims that we will have enormous market and infinite benefits as long as we embrace the strategy of global capitalism. As the novel 
shows us, there are more catastrophic risks of global capitalism than opportunities. To avoid repeating history, we should think beyond the calculating spectrum of global capitalism. Our responsibility lies in the ethical refection on the issue from the gift of death.

\section{References}

Aldama, F. L. (2008). Taylor \& Francis online. Hari Kunzru in Conversation: Wasafiri, 20(45). Retrieved from http://www.tandfonline.com/doi/abs/10.1080/02690050508589956?journalCode=rwas20

Connel, L. (2013). E-Terror: Computer viruses, class and transnationalism in transmission and one night @ the call center. Literature, migration, and the war on terror (pp. 34-35). London: Routledge.

Derrida, J. (1994). Specters of Marx. London: Routledge.

Derrida, J. (1996). The gift of death. Chicago and London: Chicago University of Chicago Press.

Karatani, K. (2014). The structure of world history: From modes of production to modes of exchange. Durham and London: Duke University Press.

Kramer, L. (2013). Far away, so close-translocation as storytelling principle in Hari Kunzru's Transmission. Postcolonial translocations: Cultural representation and critical spatial thinking (pp.77-92). Amsterdam: Rodopi.

Kunzru, Hari. (2005). Transmission. New York: Plume.

Leonard, P. (2013). Taylor \& Francis Online. “A Revolution in Code?” Hari Kunzru's Transmission and the Cultural Politics of Hacking: Textual Practice, 28(2). Retrieved from http://www.tandfonline.com/doi/abs/10.1080/0950236X.2013.824501

Lucia, K. (2013). Far away, so close-translocation as storytelling principle in Hari Kunzru's Transmission. Postcolonial translocations: Cultural representation and critical spatial thinking (pp.77-92). Amsterdam: Rodopi.

Scholte, J. A. (1997). Journal academic. Global Capitalism and the State: International Affairs, 73(3). Retrieved from https://academic.oup.com/ia/article-abstract/73/3/427/2417864?redirectedFrom=fulltext

Shelden, A. T. (2012). Cosmopolitan love: The one and the world in Hari Kunzru's Transmission. Contemporary Literature, 53(2), 348-373.

Žižek, S. (1992). Looking awry. Massachusetts: MIT Press.

Žižek, S. (1997). The plague of fantasy. London: Verso.

Žižek, S.. (2003). The puppet and the dwarf. London: MIT Press.

Žižek, S. (2006). The parallax view. Massachusetts: MIT Press. 